\title{
Roh Kudus Meterai Keselamatan Kekal Orang Percaya menurut Efesus 1:13-14
}

\author{
Yoel Benyamin \\ Sekolah Tinggi Teologi Borneo \\ Korepondensi: yoelstii@gmail.com
}

\begin{abstract}
Abstrak: Banyaknya ajaran Kekristenan yang mengajarkan mengenai keselamatan yang tidak pasti, termasuk kekeliruan pandangan mengenai karya Roh Kudus sebagai meterai keselamatan kekal orang-orang percaya, memunculkan kebimbangan sekaligus meruntuhkan konsistensi ajaran dan wibawa Alkitab. Penelitian ini bertujuan memberikan bantahan mengenai pandangan yang menolak keselamatan hanya anugerah Allah, dengan fokus penelitian pada bagaimana karya Roh Kudus mengerjakan keselamatan dalam diri orangorang percaya. Penelitian ini menggunakan metode kualitatif dengan pendekatan analisis tematik dan menganalisis teks Efesus 1:13-14 sebagai dasarnya, serta memperhatikan berbagai pandangan tentang keselamatan. Kesimpulan penelitian ini adalah bahwa pemeteraian Roh Kudus terjadi pada saat seseorang percaya Yesus sebagai Tuhan dan Juru Selamat. Roh Kudus berkarya dalam diri orang percaya, memberi perlindungan, jaminan dan pemeliharaan Allah sehingga luput dari hukuman dan memperoleh kehidupan kekal. Roh Kudus menjadi tanda bahwa orang percaya telah menjadi milik Allah oleh karena penebusan darah Kristus sesuai tanggapan iman kepada kasih karunia Allah.
\end{abstract}

Kata kunci: jaminan, meterai, Roh Kudus

Abstract: The many teachings of Christianity that teach about uncertain salvation, including the mistaken opinion of the work of the Holy Spirit as the seal of eternal salvation for believers, create doubts as well as undermine the consistency of the teachings and the authority of the Bible because it seems that its truth becomes relative. This study aims to provide a rebuttal to the opinion that rejects salvation as only God's grace, focus on research on how the work of the Holy Spirit works on salvation in believers. This study uses a qualitative method with a thematic analysis approach and analyzes the text of Ephesians 1: 13-14 as its basis, and considers various views on salvation. This research concludes that the sealing of the Holy Spirit occurs when a person believes in Jesus as Lord and Savior. The Holy Spirit works in the believer, providing protection, assurance, and care for God so that they escape punishment and gain eternal life. The Holy Spirit is a sign that the believer belongs to God because of the redemption of Christ's blood according to the faith response to God's grace.

Keywords: assurance, seal, Holy Spirit 


\section{PENDAHULUAN}

Doktrin keselamatan dalam kekristenan adalah karya sempurna yang ditetapkan Allah dalam kekekalan, dikerjakan oleh Yesus Kristus di kayu salib dan dijamin oleh Roh Kudus yang menjadi meterai bagi orang percaya. Arifianto menuliskan: "Roh Kudus menuntun kepada seluruh kebenaran Allah, sehingga orang yang dituntunnya terhindar dari siasat penyesatan." Perjalanan sejarah kekristenan tentang jaminan keselamatan ini mengalami pergumulan, khususnya dari pandangan Armenian yang mengajarkan keselamatan dapat hilang. Kaum Arminian mengatakan: "Pada akhirnya dapat kehilangan imannya dan binasa, meskipun demikian dalam Alkitab ada beberapa ayat yang menyatakan hal itu." 2 Di sisi lain menurut pemahaman gereja katolik: "Kristus memberikan bantuan dan pertolongan-Nya kepada orang yang telah dibaptiskan untuk memperoleh keselamatannya, apabila orang itu mau berusaha. Manusia diselamatkan oleh anugerah Tuhan dan atas usaha manusia itu sendiri. Dalam hal ini manusia berperan penting apakah dia selamat atau tidak." Keselamatan seolah tidak pasti dan bergantung pada perbuatan manusia yang rapuh.

Keselamatan yang tidak pasti atau tidak memiliki jaminan kekal merupakan pengajaran yang keliru dan tidak sesuai dengan Efesus $1: 13,14$. Penyelidikan akan Roh Kudus yang memeterai keselamatan sangat penting dan menjadi bantahan bagi pengajaran tentang keselamatan yang bisa hilang.

Beberapa penelitian telah dibuat tentang Roh Kudus. Sumiwi meneliti tentang peran Roh Kudus dalam kehidupan orang percaya dengan mencermati berbagai teks dalam Perjanjian

${ }^{1}$ Yonatan Alex Arifianto dan Asih Rachmani Endang Sumiwi, "Peran Roh Kudus dalam Menuntun Orang Percaya kepada Seluruh Kebenaran Berdasarkan Yohanes 16 : 13," Diegesis: Jurnal Teologi Kharismatika 3, no. 1 (2020): 1-12.

${ }^{2}$ The Works of James Arminius, vol. 1 (Ausburn: Derby \& Miller, 1853).

${ }^{3}$ J. Verkuyl, Apakah Beda Gereja Rum Katolik dan Reformasi? (Jakarta: BPK Gunung Mulia, 1968), 35.
Baru. ${ }^{4}$ Karyanya yang lain bersama dengan Arifianto lebih menekankan kepada peran Roh Kudus dalam menuntun kepada kebenaran

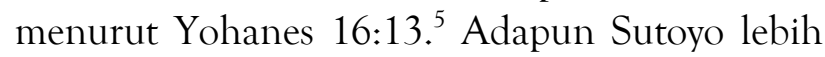
memfokuskan kepada peran Roh Kudus dalam pemberitaan Injil. ${ }^{6}$ Chandra meneliti peran Roh Kudus dalam misi Allah. ${ }^{7}$ Sedangkan yang lainnya menekankan pada peran Roh Kudus dalam pendidikan Kristen. ${ }^{8}$

Adapun karya ilmiah ini lebih berfokus tentang aspek keselamatan yang dikerjakan oleh Roh Kudus dalam keselamatan orang percaya. Ketertarikan ini didasari pengamatan terhadap kekeliruan pandangan orang Kristen tentang pemeteraian Roh Kudus dalam keselamatan. Melalui penelitian dan pengkajian literatur yang ada, tulisan ini menjadi bantahan bagi pandangan yang menolak keselamatan sepenuhnya karya anugerah Allah melalui karya meterai Roh Kudus. Seperti yang ditulis oleh Baker: "Ada yang menganggap bahwa karena Allah yang menciptakan segala sesuatu, tentu Ia bertanggungjawab atas apa saja yang terjadi, dan karena itu demi keadilan tentu Allah berutang kepada ciptaanNya untuk menyelamatkan

${ }^{4}$ Asih Rachmani Endang Sumiwi, "Peran Roh Kudus dalam Kehidupan Orang Percaya Masa Kini," Jurnal Teologi Gracia Deo 1, no. 1 (2018): 23-31.

${ }^{5}$ Arifianto dan Sumiwi, "Peran Roh Kudus dalam Menuntun Orang Percaya kepada Seluruh Kebenaran Berdasarkan Yohanes 16 : 13.”

${ }^{6}$ Daniel Sutoyo, "Peran Roh Kudus dalam Pemberitaan Injil," Antusias: Jurnal Teologi dan Pelayanan 1, no. 3 (2011): 17-26.

${ }^{7}$ Robby I. Chandra, "Peran Roh Kudus dalam Misi Allah: Ajaran yang Terlewatkan dalam Narasi Kisah Rasul 16:11," Jurnal Teologi Amreta 4, no. 1 (2020): 45-66.

${ }^{8}$ Nur Budi Santosa, "Peran Roh Kudus dalam Pelaksanaan Pendidikan Kristen,” Antusias: Jurnal Teologi dan Pelayanan 2, no. 2 (2012): 105-118; Hardi Budiyana, "Roh Kudus dalam Proses Pembelajaran Pendidikan Kristen Mewujudkan Pengajaran Kristen yang Mengandung Nilai Kekal," Jurnal Teologi Berita Hidup 1, no. 1 (2018); Imanuel Adhitya Wulanata, "Peran dan Karya Roh Kudus serta Implikasinya terhadap Pengembangan Pribadi dan Kualitas Pengajaran Guru Kristen [Roles and Work of the Holy Spirit and the Implications for the Personal Development and Teaching Quality of Christian Teachers]," POLYGLOT: Jurnal Ilmiah 14, no. 1 (2018): 19-30. 
mereka." Ini memusatkan pemikiran bahwa keselamatan adalah tanggung jawab Allah semata atas ciptaan, bukan tanggung jawab manusia. Padahal manusia ini tidak pantas menerima keselamatan, melainkan pantas menerima penghukuman Allah.

Tujuan penelitian ini adalah untuk memberikan bantahan terhadap pandangan bahwa keselamatan dapat hilang, memberikan rasa aman bagi keyakinan orang percaya bahwa keselamatan kekal oleh Allah, dan memaparkan kebenaran dalam Efesus 1:13-14 secara biblikal sebagai dasar pandangan Kristen tentang jaminan keselamatan kekal.

\section{METODE}

Karya ilmiah ini menggunakan penelitian kualitatif dengan pendekatan analisis tematik untuk mendapatkan kesimpulan yang tepat. ${ }^{10}$ Penelitian tematik adalah fokus dalam penelitian teks. Menurut Richard L. Pratt, Jr analisis tematik adalah fokus pada topik yang membicarakan tentang Allah, dunia dan tindakan penciptaan, atau aspek lainnya dari teks. Analisis tematik mempunyai daya tarik karena hikayat Perjanjian Lama berbicara tentang banyak hal. Butiran apapun dalam Perjanjian Lama dapat menjadi fokus pendekatan tematik. Dalam Perjanjian Baru tentunya ada hal yang menarik yang berhubungan dari salah satu epistle atau surat Paulus yang berhubungan mengenai tema Pemeteraian Roh Kudus. Penulis menjelaskan mengenai Karya pemeteraian Roh Kudus yang dibicarakan oleh Paulus dalam Efesus 1:13-14.

Bentuk analisis tematik yang paling dominan adalah teologi sistematika tradisional. Pengakuan-pengakuan iman dan katekismus yang lebih tua sering memakai sumber-sumber Perjanjian Lama dan Perjanjian Baru sebagai teks bukti (proof-teks) dalam mendefinisikan dan mendukung kepercayaan-kepercayaan doktrinal,

${ }^{9}$ Charles Baker, A Dispensational Theology (Jakarta: Pustaka Alkitab Anugerah, 2009), 366.

${ }^{10}$ Richard L Pratt Jr., Ia Berikan Kita Kisah-Nya: Panduan bagi Siswa Alkitab untuk Menafsirkan Narasi Perjanjian Lama (Surabaya: Penerbit Momentum, 2005), 101. serta ikut menganalisis dan mensintesis apa yang Paulus katakan tentang pemeteraian Roh Kudus. ${ }^{11}$ Seperti misalnya, apa ajaran-ajaran Pemeteraian Roh Kudus (Efesus 1:13-14). Maksudnya ialah fokus membicarakan mengenai Roh Kudus dalam teks tersebut. Jadi, bisa dikatakan bahwa tipe analisis teologi sistematika lebih menekankan salah satu aspek yang penting yang terdapat dalam teks untuk memperkaya sistem teologis. Kajian ini menggunakan penafsiran literal, gramatikal, konteks dan teologis.

\section{PEMBAHASAN}

\section{Makna Pemeteraian oleh Roh Kudus}

Ada beberapa teks dalam surat Paulus yang berbicara tentang Roh Kudus sebagai meterai seperti 1 Korintus 1:22, Efesus 1:13 dan 4:30. Firman Tuhan dalam Efesus 1:13 sangatlah jelas: "Di dalam Dia kamu juga - karena kamu telah mendengar firman kebenaran, yaitu Injil keselamatanmu - di dalam Dia kamu juga, ketika kamu percaya, dimeteraikan dengan Roh Kudus, yang dijanjikan-Nya itu." Sekalipun dijelaskan bahwa Roh Kudus sebagai meterai, ada beberapa istilah yang digunakan rasul Paulus yang membuat para teolog harus memberi penafsiran sederhana dan dapat dimengerti, misalnya penggunaan kata "kamu" bukannya kata "kita" dalam ayat ini. Untuk menjelaskannya, perhatikan ayat 6 "...yang dikaruniakan-Nya kepada kita di dalam Dia ..." dan ayat 11 "...di dalam Dialah kami mendapat bagian yang dijanjikan ..." LAI menerjemahkan kata "kami" dengan kata "kita" dalam ayat 6 di atas karena menurut Abineno, mereka (termasuk LAI) menafsirkan hemas dalam arti yang luas (semua orang Kristen) dan karena itu diterjemahkan "kita." Hal ini sesuai dengan pendapat Rendtorff, Staab, Greijdonus, Grosheide, dan lain-lain. ${ }^{12}$ Kami, menurut Abineno, adalah orang-orang Kristen Yahudi saja

${ }^{11}$ Gordon D. Fee, God's Empowering Presence: the Holy Spirit in the Letters of Paul (Peabody: Hendrickson Publishers, 1994), 5.

${ }^{12}$ J. L. Ch. Abineno, Tafsiran Alkitab: Surat Efesus (Jakarta: BPK Gunung Mulia, 1989), 30. 
karena ayat 11 jelas tertulis: "kami yang dari semula ditentukan untuk menerima bagian itu sesuai dengan maksud Allah" dan dalam ayat 13 tertulis: "...karena kamu telah mendengar firman kebenaran ..."13 Jadi, baik orang Kristen Yahudi maupun orang Kristen bukan Yahudi, semuanya mendapat kesempatan untuk menjadi percaya. Pemeteraian oleh Roh Kudus meliputi orang percaya di segala tempat, abad, dan masa yang menerima karya keselamatan yang dilakukan Yesus di salib. Tanda meterai merupakan tanda jaminan yang sah akan kepastian keselamatan orang percaya.

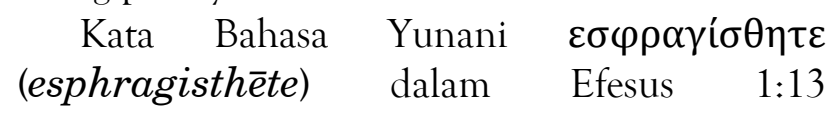

diterjemahkan: kamu ditandai dengan segel atau dalam TB diterjemahkan: "kamu dimeteraikan." Ini menandakan kepastian keselamatan sebab Roh Kudus yang mengerjakan pemeteraiannya. Roh Kudus menjamin orang percaya menerima kehidupan kekal di sorga. Memiliki hidup kekal berarti memiliki keselamatan kekal. Kehidupan atau jaminan yang mempunyai akhir adalah kehidupan atau jaminan yang bersifat sementara. Jaminan itu dimiliki sampai memperoleh seluruhnya. Ryrie mengatakan: "Pemeteraian mencakup kepemilikan dan meyakinkan kita tentang jaminan janji-janji Allah kepada kita, terutama sekali tentang keselamatan kita. ${ }^{15}$ Kita telah dijadikan milik Allah oleh penebusan darah Kristus melalui tanggapan iman kita kepada kasih karunia Allah. Barclay mengatakan: "Meterai dalam Perjanjian Baru juga mempunyai gagasan penandaan kepemilikan, cap yang menunjukkan bahwa kita adalah buatan Allah." ${ }^{16}$ Ini menjadi alasan mengapa orang percaya memiliki status baru setelah percaya, karena mereka adalah ciptaan baru. Sebab orang percaya dimeteraikan ketika percaya, seperti dikatakan oleh Sumiwi: "Allah yang memeteraikan orang percaya, dan pemeteraian itu dilakukan oleh Roh Kudus ketika

\footnotetext{
${ }^{13}$ Ibid.

${ }^{14}$ Ibid.

${ }^{15}$ Charles C. Ryrie, Teologi Dasar, vol. 2 (Yogyakarta: Andi Offset, 2013), 135.

${ }^{16}$ William Barclay, The Promise of the Spirit (Philadelphia: The Westminster Press, 1960), 15.
}

seseorang percaya." 17 Pekerjaan ini dilakukan oleh Roh Kudus.

Kata "esphragisthēte" dari kata $\sigma \varphi \rho \alpha \gamma i \zeta \omega$ (sphragizō) artinya "menyegel (agar aman atau tertutup), menandai dengan segel atau mengesahkan dengan segel, mengakui." ${ }^{18}$ Dalam NAGL dapat diterjemahkan "menandai dengan segel, menyembunyikan, membedakan dengan sebuah tanda, mengesankan atau mencamkan dengan tanda penerimaan, membuat sebuah pernyataan atau pengumuman yang serius." ${ }^{19}$ Bailey mengajarkan bahwa Allah Bapa telah membeli kita dengan darah Kristus dan telah menempatkan Roh Kudus-Nya di dalam kita sebagai suatu meterai yang menandakan bahwa kita adalah milik-Nya dan bahwa kita sedang menantikan penebusan akhir kita pada hari kebangkitan yang mulia itu. ${ }^{20}$

Stott juga memberikan pengajaran yang hampir sama dengan Bailey di atas bahwa pada zaman dahulu binatang bahkan budak dicap dengan meterai pemiliknya sebagai tanda kepemilikan binatang dan budak itu. Namun meterai demikian dipasang di sisi luar, sedangkan meterai Allah dipasang di sisi dalam. Pembaptisan adalah tanda di luar yang kelihatan, sedangkan Allah memeteraikan umat-Nya dengan Roh supaya mereka diketahui sebagai milik-Nya. $^{21}$

Penulis sangat setuju dengan apa yang dikemukakan Stott di atas bahwa pembaptisan air dan Allah memeteraikan umat-Nya dengan Roh Kudus adalah dua hal yang berbeda dan tidak dapat disamakan ataupun dianggap sama. Jadi penulis tidak setuju atau menolak apa yang

\footnotetext{
${ }^{17}$ Sumiwi, "Peran Roh Kudus dalam Kehidupan Orang Percaya Masa Kini.”

${ }^{18}$ Hasan Sutanto, Perjanjian Baru Interlinear YunaniIndonesia dan Konkordansi Perjanjian Baru (PBIK), vol. 2 (Jakarta: Lembaga Alkitab Indonesia, 2003), 739.

${ }^{19}$ Wesley J. Perschbacher, ed., The New Analytical Greek Lexicon (NAGL) (Massachusetts: Hendrickson Publishers, 1994), 398.

${ }^{20}$ Brian J. Bailey, Prajurit Kristus: Suatu Eksposisi dari Surat Paulus kepada Jemaat di Efesus (Jakarta: Harvest Publication House, 2002), 33.

${ }^{21}$ John R. W. Stott, Efesus: Mewujudkan Masyarakat Baru di Dalam dan Melalui Yesus Kristus, trans. Martin B. Dainton dan H. A. Oppusunggu (Jakarta: Yayasan Komunikasi Bina Kasih, 2003), 43.
} 
diungkapkan oleh Abineno bahwa “... dalam Perjanjian Baru baptisan itu erat berhubungan dengan pemberian Roh Kudus." ${ }^{22}$ Dalam hal ini Abineno mendukung pendapat Schlier yang mengatakan tentang orang-orang Yahudi yang bertobat dan dibaptis bahwa mereka "dimeteraikan" di dalam Dia. Abineno juga menyetujui pendapat Van Leeuwen dan Masson yang menghubungkan sphragizein dengan baptisan. Alasannya karena hubungan itu jelas sekali dalam Kisah Rasul 19:2-3. Alasan lain karena dalam abad-abad pertama baptisan sering disebut sphragis, yang mungkin berasal dari kata sphragizein yang dipakai dalam Perjanjian Baru. ${ }^{23}$

Penulis berpendapat bahwa "dimeteraikan" identik dengan dikuduskan atau disucikan karena Roh Kudus berfungsi "menyucikan atau menguduskan." Paling kurang ada tiga ayat Alkitab yang mengajarkan tentang fungsi Roh Kudus yang menguduskan atau menyucikan. Ketiga ayat tersebut adalah Roma 15:16 ("yang disucikan oleh Roh Kudus”), 2 Tesalonika 2:13 ("dalam Roh yang menguduskan kamu”), 1 Petrus 1:2 (“yang dikuduskan oleh Roh”). Kata ayı $\alpha \mu \omega$ (agiasmō) dalam 2 Tesalonika 2:13 artinya "menguduskan, menahbiskan, menghormati sebagai yang kudus." ${ }^{24}$ Ini menegaskan fungsi Roh Kudus menyucikan dan berkorelasi dengan makna dimeteraikan sebagai pengudusan.

Pemeteraian oleh Roh Kudus menurut Efesus 1:13 terjadi jika memenuhi dua syarat: mendengar Firman kebenaran yaitu Injil keselamatan dan percaya. Selain Efesus 1:13, ada juga ayat-ayat Alkitab lain yang mengungkapkan secara implisit bahwa ada dua syarat mendengar dan percaya - untuk memperoleh keselamatan dalam Kristus Yesus. Ayat-ayat Alkitab itu adalah: Yohanes 5:24 (mendengar dan percaya), Roma 10:17 (pendengaran dan iman), 2 Timotius 3:15 (mengenal dan iman), Wahyu 3:20 (mendengar dan membukakan pintu). Harus dua syarat untuk memperoleh

\footnotetext{
${ }^{22}$ Abineno, Tafsiran Alkitab: Surat Efesus, 32.

${ }^{23}$ Ibid.

${ }^{24}$ Hasan Sutanto, Perjanjian Baru Interlinear Yunani Indonesia dan Konkordansi Perjanjian Baru (PBIK), vol. 1 (Jakarta: Lembaga Alkitab Indonesia, 2003), 1043.
}

keselamatan dalam Kristus Yesus karena "iman timbul dari pendengaran, dan pendengaran oleh firman Kristus" (Rm. 10:17). Firman Kristus identik dengan "Firman kebenaran, yaitu Injil keselamatanmu" (Ef. 1:13).

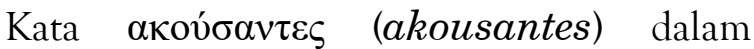
Efesus 1:13 diterjemahkan "karena telah mendengar." ${ }^{25}$ Kata akousantes dari kata

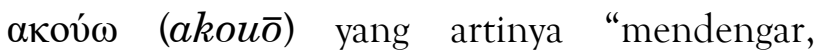
mendengarkan, mendengar (dalam pemeriksaan perkara), mengetahui, menaati, mengerti." 26 Jadi, ungkapan "telah mendengar Firman kebenaran, yaitu Injil keselamatanmu" mengandung arti "telah mendengar untuk mengerti" tentang Injil

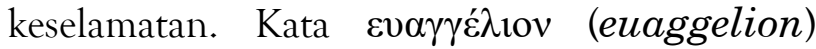
artinya Kabar Baik. ${ }^{27}$ Ini hanya kabar baik yang berhubungan dengan penyedian keselamatan dalam penebusan Yesus Kristus. Seseorang untuk memperoleh keselamatan harus mendengar Kabar Baik atau Firman Kebenaran. Hal ini karena Kitab Suci atau Firman Tuhan memberi hikmat untuk menuntun kepada keselamatan oleh iman dalam Kristus Yesus, mengajar, menyatakan kesalahan, memperbaiki kelakuan, mendidik orang dalam kebenaran, dan memperlengkapi kita untuk setiap pekerjaan yang baik (band. 2Tim. 3:15-17). Salah satu fungsi Alkitab atau Firman Allah adalah memberi hikmat menuntun kepada keselamatan oleh iman dalam Kristus Yesus. Jadi dapat disimpulkan bahwa seseorang mampu beriman dalam Kristus Yesus, karena mendengar Firman Tuhan yang memberi hikmat untuk menuntun kepada keselamatan oleh iman dalam Kristrus Yesus.

Kata $\pi 1 \sigma \tau \varepsilon v ́ \sigma \alpha v \tau \varepsilon \varsigma$ (pisteusantes) dalam Efesus 1:13 diterjemahkan "ketika percaya." 28 Kata pisteusantes dari kata $\pi \_\tau \varepsilon v ́ \omega$ (pisteūo) yang artinya "percaya mempunyai iman kuat dan yakin boleh mempercayakan." ${ }^{29}$ Yohanes 1:12 tertulis: "Tetapi semua orang yang menerima-

${ }^{25}$ Ibid, 1027.

${ }^{26}$ Sutanto, Perjanjian Baru Interlinear Yunani-Indonesia dan Konkordansi Perjanjian Baru (PBIK), vol. 2, hal. 37.

${ }^{27}$ Sutanto, Perjanjian Baru Interlinear Yunani-Indonesia dan Konkordansi Perjanjian Baru (PBIK), vol. 1, hal. 1027.

${ }^{28}$ Ibid.

${ }^{29}$ Sutanto, Perjanjian Baru Interlinear Yunani-Indonesia dan Konkordansi Perjanjian Baru (PBIK), vol. 2, hal. 639-641. 
Nya diberi-Nya kuasa supaya menjadi anak-anak Allah, yaitu mereka yang percaya dalam namaNya." Jadi, mereka yang percaya dalam nama-Nya adalah semua orang yang menerima-Nya. Mereka diberi kuasa menjadi anak-anak Allah. Kata menerima dalam teks Yunani ialah $\varepsilon \lambda \alpha \beta o v(e l a b o n)$ yang merupakan kata kerja bentuk imperfect orang ketiga jamak dalam EDNT ditulis "They received Him." ${ }^{30}$ Penggunaan imperfek dalam Bahasa Yunani menunjukkan kegiatan yang telah berlangsung. MenerimaNya dalam hal ini mengandung arti aplikatif yaitu percaya kepada Yesus Kristus sebagai Tuhan dan Juru Selamatnya pribadi. Itu berarti ketika menerima Yesus Kristus dimeteraikan dengan Roh Kudus yang dijanjikan-Nya itu. Seseorang dimeteraikan dengan Roh Kudus ketika ia percaya Yesus Kristus sebagai Tuhan dan Juruselamatnya secara pribadi, bukan saat mengikuti upacara gerejawi seperti pembaptisan air. Dimeteraikan identik dengan dikuduskan. Jadi ketika seseorang menjadi percaya, saat itulah ia dimeteraikan atau disegel atau disahkan menjadi orang-orang kudus satu kali untuk selama-lamanya. Menurut penulis, yang dimaksud dengan percaya kepada Tuhan Yesus Kristus, seperti yang dijelaskan dalam Yohanes 1:12 di atas, yaitu menerima Dia sebagai Tuhan dan Juruselamat.

\section{Roh Kudus adalah Jaminan}

Orang percaya menyadari bahwa keadaan tubuh ini masih di dalam dunia dan belum berada dalam kehidupan kekal sorgawi. Oleh sebab itu keselamatan, sekalipun itu pasti, masih merupakan perspektif di masa mendatang. Saragih menuliskan: "Keselamatan itu bukan suatu keadaan yang sampai atau mencapai kesempurnaan tetapi merupakan suatu keadaan perjalanan, bertumbuh di dalam Allah, untuk Allah serta melalui kuasa Allah." ${ }^{31}$ Ini

${ }^{30}$ Horst Robert Balz dan Schneider Gerhard, ed., Exegetical Dictionary of the New Testament (Grand Rapids, MI: William B. Eerdmans Publishing Company, 1994), 337.

${ }^{31}$ Erman S. Saragih, "Soteriologi Hypergrace dalam Perspektif Teologi Martin Luther Dan Alkitab," Jurnal Teologi Cultivation 1, no. 2 (2017): 235-251. mengandung pemikiran bahwa keselamatan tersebut merupakan "proses menuju" sehingga perlu suatu jaminan bahwa keselamatan itu pasti. Dalam konsep jaminan inilah Roh Kudus sebagaimana diajarkan Paulus memeteraikan keselamatan orang percaya.

Dalam Efesus 1:14 dikatakan: "Roh Kudus itu adalah jaminan bagian kita sampai kita memperoleh seluruhnya, yaitu penebusan yang menjadikan kita milik Allah, untuk memuji kemuliaan-Nya." Apakah sebenarnya peran Allah Tritunggal dalam penyelamatan manusia sehingga keselamatan itu terwujud? Untuk menjawab pertanyaan ini, maka perlu menjawab dahulu pertanyaan: Siapakah penyebab keselamatan? Penyebab keselamatan menurut Lantang adalah pembahasan tentang pribadipribadi Allah yang berperan sehingga keselamatan itu terwujud, yaitu: pertama, ALLAH sebagai perencana kekal dari segala sesuatu dan penyebab asal mulanya keselamatan atau the originating cause (2Tim. 1:9); kedua, YESUS KRISTUS sebagai perantara yang memenuhi semua tuntutan Allah dan telah dilaksanakan di kayu salib, ganti dan untuk orang-orang yang percaya kepada-Nya atau the meritorious cause (Mat. 20:28, 2Kor. 5:21, 1Ptr. 3:18); ketiga, ROH KUDUS yang membuat orang percaya lahir baru dan hidup suci. Dialah yang menjadi penyebab atau pelaksana sehingga keselamatan itu menjadi pengalaman pribadi orang percaya atau the efficient cause (Yoh. 3:5; Gal. 5:16). Peranan Roh Kudus bukan hanya sebagai pelaksana keselamatan (efficient cause) tetapi juga sebagai jaminan semua hak orangorang tebusan-Nya untuk menerima seluruh janji-janji Allah pada saat hari penebusan. "Roh Kudus memeteraikan orang percaya sampai hari penebusan. Seandainya keselamatan bisa hilang, maka meterai-Nya tidak akan sampai hari penebusan." ${ }^{\text {2 }}$

Antara kebenaran dalam Efesus 1:13 dan 1:14 terdapat paradoks, yaitu pernyataan yang seolah-olah berlawanan dengan pendapat umum atau kebenaran tetapi kenyataannya

\footnotetext{
${ }^{32}$ Ryrie, Teologi Dasar, vol. 2, hal. 95.
} 
mengandung kebenaran, ${ }^{33}$ sebab di satu pihak dikatakan segala berkat rohani di dalam sorga telah dikaruniakan. Di pihak lain dikatakan Roh Kudus adalah jaminan bagian sampai memperoleh seluruhnya, yaitu pada saat penebusan. Manakah yang benar: sudah dikaruniakan atau nanti saat penebusan kelak? Yang terpenting di sini haruslah mengerti lebih dahulu apa yang dimaksud dengan "penebusan" pada umumnya dan khususnya dalam Efesus 1:14 tersebut.

Penebusan dalam bahasa Inggris "redemption" dan didefinisikan secara singkat oleh Leon Moris yang dikutip oleh Robert P. Lightner sebagai "the price paid" ${ }^{34}$ yang artinya "lunas terbayar." Menurut Baker, ada empat kata yang digunakan dalam Perjanjian Baru untuk kata penebusan:

(1) "AGORAZO” perkataan ini biasa digunakan di pasar yang mengandung arti "membeli di pasar", I Korintus 6:20), 7:23, II Petrus 2:1, Wahyu 5:9, 14:3-4; (2) "EXAGORAZO" yang bukan hanya berarti membayar, tetapi menebus, membayar keluar dari pasar, untuk memulihkan dari kuasa yang lain, Galatia 3:13, 4:5; (3) "LUTROO" artinya membebaskan dengan pembayaran suatu tebusan (sebagai kata kerja, Lukas 24:21, Titus 2:14, I Petrus 1:18; sebagai kata benda "lutron" Matius 20:28, Markus 10:45; dan sebagai kata benda "lutrosis" Lukas 1:68, 2:38, Ibrani 9:12; (4) "APOLUTROSIS" yang artinya suatu efek pembebasan oleh pembayaran tebusan, Lukas 21:28, Roma 3:24, 8:23, I Korintus 1:30, Efesus $1: 7,14,4: 30$, Kolose 1:14, Ibrani 9:15. ${ }^{35}$

Menurut Abineno, penebusan yang dimaksud di sini (Ef. 1:14) ialah penebusan penuh atau keselamatan kekal yang akan diterima orang percaya. $^{36}$ Ia menambahkan

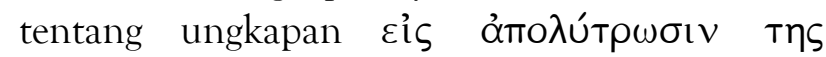

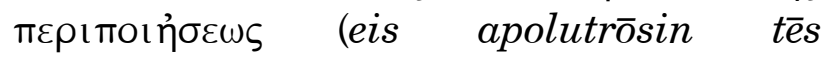
peripoiēseōs). Pendapat para penafsir mengenai ungkapan ini tidak sama. Ada yang menerjemahkan dengan "sampai kita memperoleh penebusan," "untuk penebusan

\footnotetext{
${ }^{33}$ Anton M. Moeliono, Kamus Besar Bahasa Indonesia (Jakarta: Balai Pustaka, 1990), 648.

${ }^{34}$ Robert P. Lightner, Evangelical Theology (Michigan: Baker Book House, 1986), 194.

${ }^{35}$ Baker, A Dispensational Theology, 349-350.

${ }^{36}$ Abineno, Tafsiran Alkitab: Surat Efesus, 33.
}

yang menjadikan kita milik Allah," "untuk penebusan yang kita miliki," "untuk penebusan yang menguasai (warisan sorgawi)," dan "untuk penebusan milik yang diperoleh Allah." 37

Menurut peneliti, "pengudusan" dapat dibagi ke dalam tiga kurun waktu, yaitu: pengudusan lalu (Gal. 3:13, Rm. 3:24, Ef. 1:7, 1Ptr. 1:18-19); pengudusan kini (Tit. 2:14); pengudusan yang akan datang ( $\mathrm{Rm}$. 8:22-23, 1Kor. 15:52, Ef. 1:14, Flp. 3:20-21). Adapun yang dimaksud dengan pengudusan nanti adalah pengudusan yang akan datang, yaitu pada saat Kristus menyatakan diri-Nya (band. 1Yoh.3:2-3). Dalam Efesus 1:14 Roh Kudus adalah jaminan bagian kita sampai kita memperoleh seluruhnya, yaitu saat penebusan, saat Kristus menyatakan diri-Nya.

Kata $\alpha \rho \rho \alpha \beta \omega ́ v$ (arrabōn) dalam Efesus 1:14 diterjemahkan "panjar; jaminan." ${ }^{38}$ Dalam NAGL kata tersebut dapat diterjemahkan "bersungguh-sungguh atau betul dengan janji, "(uang) panjar atau uang muka." 39 Stott menyatakan bahwa

\footnotetext{
“arrabon" (jaminan) berawal dari kata Ibrani kuno, yang diambil alih pedagang Fenisia dan kemudian orang Yunani. Dalam transaksi perdagangan kuno, istilah itu dipakai untuk uang tanggungan. Uang itu bukan saja jaminan akan dibayar nanti, melainkan bagian dari pembayaran itu. Roh Kudus adalah jaminan bahwa Allah akan mengaruniakan keselamatan penuh. ${ }^{40}$
}

Jadi, Roh Kudus diberikan kepada orang percaya ketika ia percaya. Pemberian itu menjadi seperti "down payment" atau "uang muka" yang mengandung arti bahwa Allah memberi Roh Kudus untuk menjamin semua hak orang pecaya sebagai anak-anak-Nya akan diberikan kini di sini dan nanti kelak dalam penggenapan penebusan. Allah sebagai perencana dan penyebab asal mulanya keselamatan, Yesus Kristus sebagai pelaksana keselamatan, dan Roh Kudus adalah

\footnotetext{
${ }^{37}$ Ibid.

${ }^{38}$ Sutanto, Perjanjian Baru Interlinear Yunani-Indonesia dan Konkordansi Perjanjian Baru (PBIK), vol. 2, hal. 115.

${ }^{39}$ Perschbacher, The New Analytical Greek Lexicon (NAGL), 54.

${ }^{40}$ Stott, Efesus: Mewujudkan Masyarakat Baru di Dalam dan Melalui Yesus Kristus, 43.
} 
penyebab atau pelaksana sehingga keselamatan itu menjadi pengalaman pribadi orang percaya.

\section{KESIMPULAN}

Pemeteraian oleh Roh Kudus atas orang percaya terjadi ketika seorang percaya. Setelah memeteraikan, Roh Kudus berkarya dalam diri seorang percaya secara tidak terbatas. Pemeteraian Roh Kudus bertujuan untuk memberi perlindungan, jaminan dan pemeliharaan Allah. Perlindungan berarti orang percaya terluput atau terlindungi dari hukuman kekal sehingga orang percaya memperoleh hidup yang kekal. Ini menjadi dasar pemikiran Kristen bahwa janji kehidupan kekal di sorga adalah pasti karena Roh Kudus menjadi jaminan. Jaminan itu dimiliki sampai orang percaya memperoleh seluruhnya. Meterai adalah juga tanda pengakuan bahwa kita sesungguhnya adalah anak-anak dan bukti bahwa Allah benarbenar telah menerima iman kita. Kita telah dijadikan milik Allah oleh penebusan darah Kristus melalui tanggapan iman kita kepada kasih karunia Allah. Roh Kudus diberikan sebagai jaminan bahwa orang percaya akan memperoleh apa yang dijanjikan tersebut. Roh Kudus juga berkarya memberikan pemeliharaan atas orang percaya, yakni dengan membantu dalam kelemahan orang percaya dan berdoa untuk orang percaya.

\section{KEPUSTAKAAN}

Abineno, J. L. Ch. Tafsiran Alkitab: Surat Efesus. Jakarta: BPK Gunung Mulia, 1989.

Arifianto, Yonatan Alex, dan Asih Rachmani Endang Sumiwi. "Peran Roh Kudus dalam Menuntun Orang Percaya kepada Seluruh Kebenaran Berdasarkan Yohanes 16: 13.” Diegesis: Jurnal Teologi Kharismatika 3, no. 1 (2020): 1-12.

Bailey, Brian J. Prajurit Kristus: Suatu Eksposisi dari Surat Paulus kepada Jemaat di Efesus. Jakarta: Harvest Publication House, 2002.

Baker, Charles. A Dispensational Theology. Jakarta: Pustaka Alkitab Anugerah, 2009.

Balz, Horst Robert, dan Schneider Gerhard, ed.
Exegetical Dictionary of the New Testament. Grand Rapids, MI: William B. Eerdmans Publishing Company, 1994.

Barclay, William. The Promise of the Spirit. Philadelphia: The Westminster Press, 1960.

Budiyana, Hardi. "Roh Kudus dalam Proses

Pembelajaran Pendidikan Kristen

Mewujudkan Pengajaran Kristen yang

Mengandung Nilai Kekal.” Jurnal Teologi

Berita Hidup 1, no. 1 (2018).

Chandra, Robby I. "Peran Roh Kudus dalam Misi Allah: Ajaran yang Terlewatkan dalam Narasi Kisah Rasul 16:11.” Jurnal Teologi Amreta 4, no. 1 (2020): 45-66.

Fee, Gordon D. God's Empowering Presence: the Holy Spirit in the Letters of Paul. Peabody: Hendrickson Publishers, 1994.

Lightner, Robert P. Evangelical Theology. Michigan: Baker Book House, 1986.

Moeliono, Anton M. Kamus Besar Bahasa Indonesia. Jakarta: Balai Pustaka, 1990.

Perschbacher, Wesley J., ed. The New Analytical Greek Lexicon (NAGL). Massachusetts: Hendrickson Publishers, 1994.

Pratt Jr., Richard L. Ia Berikan Kita Kisah-Nya: Panduan bagi Siswa Alkitab untuk Menafsirkan Narasi Perjanjian Lama. Surabaya: Penerbit Momentum, 2005.

Ryrie, Charles C. Teologi Dasar. Vol. 2. Yogyakarta: Andi Offset, 2013.

Santosa, Nur Budi. "Peran Roh Kudus dalam Pelaksanaan Pendidikan Kristen.” Antusias: Jurnal Teologi dan Pelayanan 2, no. 2 (2012): 105-118.

Saragih, Erman S. "Soteriologi Hypergrace dalam Perspektif Teologi Martin Luther Dan Alkitab." Jurnal Teologi Cultivation 1, no. 2 (2017): 235-251.

Stott, John R. W. Efesus: Mewujudkan Masyarakat Baru di Dalam dan Melalui Yesus Kristus. Diterjemahkan oleh Martin B. Dainton dan H. A. Oppusunggu. Jakarta: Yayasan Komunikasi Bina Kasih, 2003.

Sumiwi, Asih Rachmani Endang. "Peran Roh Kudus dalam Kehidupan Orang Percaya Masa Kini.” Jurnal Teologi Gracia Deo 1, no. 1 (2018): 23-31.

Sutanto, Hasan. Perjanjian Baru Interlinear Yunani- 
Indonesia dan Konkordansi Perjanjian Baru (PBIK). Vol. 2. Jakarta: Lembaga Alkitab Indonesia, 2003.

—. Perjanjian Baru Interlinear Yunani-Indonesia dan Konkordansi Perjanjian Baru (PBIK). Vol. 1. Jakarta: Lembaga Alkitab Indonesia, 2003.

Sutoyo, Daniel. "Peran Roh Kudus dalam Pemberitaan Injil.” Antusias: Jurnal Teologi dan Pelayanan 1, no. 3 (2011): 17-26.

Verkuyl, J. Apakah Beda Gereja Rum Katolik dan Reformasi? Jakarta: BPK Gunung Mulia, 1968.

Wulanata, Imanuel Adhitya. "Peran dan Karya Roh Kudus serta Implikasinya terhadap Pengembangan Pribadi dan Kualitas Pengajaran Guru Kristen [Roles and Work of the Holy Spirit and the Implications for the Personal Development and Teaching Quality of Christian Teachers]." POLYGLOT: Jurnal Ilmiah 14, no. 1 (2018): 19-30.

The Works of James Arminius. Vol. 1. Ausburn: Derby \& Miller, 1853. 